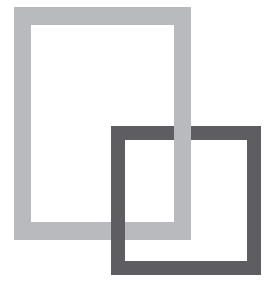

\title{
PROGRAMY OCHRONY I OPIEKI NAD ZABYTKAMI - NIEDOCENIONY ELEMENT POLSKIEGO SYSTEMU OCHRONY ZABYTKÓW
}

Programs for the protection and care of monuments - an underestimated element of the Polish system of monument protection

\section{Andrzej Siwek*}

SUMMARY: Under the Act of 23 July 2003 on the Protection and Guardianship of Monuments, a coherent model for caring for historic monuments and sites on both central and local levels was introduced. This concept is intertwined with monitoring and flow of information. The system of managing documents is aimed at optimising actions pertaining to the protection of cultural heritage. As there is a clear hierarchy of these documents, which can also correlate with each other, there are sound reasons behind establishing a coherent protection policy - from municipal/communal level to the central one. National, regional, district, and municipal/communal programmes pertaining to care for historic monuments and sites are strategic tools which shape policy, direct actions towards specific aims, and reflect the will. In a number of cases, however, no programmes have ever been developed. Administrative and legal supervision is still the predominant model in the protection of monuments and sites. The period of 2003 - 2016 was the time to „become familiar” with the new tool applied in heritage protection and management. One should learn from these experiences and promote the idea of devising a coherent strategy aimed at protecting historic monuments and sites by implementing programmes on all administrative levels.

KEY WORDS: Protection of historic monuments and sites, care for historic monuments and sites, guardianship of monuments and sites, heritage management, local government, strategic documents.

\section{Wprowadzenie}

Upodstaw dyskusjinatematzałożeńsystemusłużb konserwatorskich w Polsceznajdujemypytania ogólniejsze. Dotyczą one rozumienia przedmiotu ochrony, oczekiwanego modelu ochrony zabytków, sposobów działań i podziału odpowiedzialności pomiędzy uczestnikami działań. ${ }^{1}$ Stąd tak wiele uwagi skupia rozważanie organizacji i zakresów kompetencji służb konserwatorskich państwowych i samorządowych. ${ }^{2}$ Stąd znaczenie nurtu refleksji doktrynalno teoretycznej, który próbuje wskazać kierunek ewolucji systemu, od ochrony administracyjno prawnej, do zarządzania dziedzictwem. ${ }^{3}$

* PhD Andrzej Siwek, National Heritage Institute, Regional Department in Krakow https://orcid.org/0000-0002-3255-8768

1 Szmygin B., Teoria i kryteria wartościowania dziedzictwa jako podstawa jego ochrony /w:/ II Kongres Konserwatorów Polskich. Warszawa - Kraków 6-9 października 2015. Tezy, red. Jasieńko J., Kadłuczka A., Warszawa - Kraków 2015, s. 53-58; Araoz G. F., Tendencje dziedzictwa dziś i jutro - z perspektywy ewolucji filozofii I teorii konserwacji /w:/ II Kongres Konserwatorów ..., s. 19-25; Dobosz P., Systemy prawne ochrony zabytków z perspektywy teorii prawa administracyjnego, Kraków 2015, s.184-202.

2 Konopka M., Zalasińska K., Nic dwa razy się nie zdarza, Biuletyn Informacyjny PKN ICOMOS, styczeń - marzec 2016; Nr 1(32) 2016, s. 17-24.

3 Purchla J., Dziedzictwo kulturowe a kapitat społeczny/w:/ Dlaczego i jak w nowoczesny sposób chronić dziedzictwo kulturowe, red. Rottermund A., Warszawa 2014, s. 21-30. 
Na razie jednak, w naszym systemie, trudno znaleźć działające mechanizmy, które do takiego modelu prowadzą. ${ }^{4}$ Innym postulatem systemowym pozostającym wciąż tylko w sferze dyskusji jest kwestia monitoringu zasobu zabytków i monitoring skuteczności działań na rzecz ochrony tego zasobu. ${ }^{5}$

Świadomość zmian w otaczającym nas świecie idzie w parze ze świadomością potrzeb ewolucji narzędzi ochrony zabytków. Szukając rozwiązań budujemy kolejne koncepcje z myślą o przyszłości, zakładając a priori wyczerpanie możliwości działań w obecnie obowiązującym systemie. ${ }^{6}$ Jednak, czy faktycznie wyczerpaliśmy je wszystkie? Czy nie ma mechanizmów, które odpowiednio użyte mogły by nas zbliżyć do optymalizacji działań? Ustawa o ochronie zabytków i opiece nad zabytkami z 2003 wprowadziła w obieg formalny nieznane wcześniej systemowi dokumenty - krajowy program ochrony zabytków oraz wojewódzkie, powiatowe i gminne programy opieki nad zabytkami. ${ }^{7} \mathrm{~W}$ świetle zapisów ustawowych są to dokumenty o charakterze strategiczno zarządczym. Zatem służące wdrażaniu modelu zarządzania dziedzictwem. Ponad dwunastoletni okres obowiązywania ustawy od 2003 prawie do połowy 2016 - pozwala już na wyciąganie wniosków, co do znaczenia i skuteczności owej propozycji ustawowej. Analizy dotyczące konfrontacji intencji ustawodawcy (znanych choćby z autorskich komentarzy do ustawy z 2003$)^{8}$, z praktyką realizacyjną dają podstawy do snucia wniosków na tematy systemowe. Bowiem zapisany w ustawie model funkcjonowania planów opieki nad zabytkami na każdym ze szczebli samorządu terytorialnego, z zaprojektowanym mechanizmem monitoringu, weryfikacji i przepływu informacji (wymagane ustawowo sprawozdania $\mathrm{z}$ realizacji programu) nosi znamiona obiecującej konstrukcji, która może posłużyć mobilizacji do ochrony i upowszechnieniu odpowiedzialności za zabytki. Jednak w praktyce model ten nigdy nie zafunkcjonował w pełni, nie stał się systemem zamkniętym, zasilanym informacjami z realizacji wcześniejszych edycji dokumentów oraz dokumentami samorządu regionalnego i lokalnego. Nie widać symptomów zmian w tym kierunku.

Nasuwa się wniosek, iż model ochrony z udziałem planów ochrony i opieki nad zabytkami zapisany w ustawie jest niedocenionym elementem systemu ochrony zabytków w Polsce. Elementem, który w znaczącym stopniu powinien poprawić synergię funkcjonowania państwowej służby konserwatorskiej i samorządu, a finalnie pomóc w budowaniu docelowego modelu zarządzania partycypacyjnego dziedzictwem, służącego skuteczniejszej ochronie zabytków w uwarunkowaniach współczesności. Przyjrzyjmy się jednak problemowi systematycznie, poszukajmy odpowiedzi na pytanie - czemu model nie spełnia oczekiwań?

\section{Model ustawowy}

Ustawa z dnia 23 lipca 2003 roku o ochronie zabytków i opiece nad zabytkami z jednej strony

4 Pawłowska K., Interesariusze w procesach zarządzania obiektami wpisanymi na listę światowego dziedzictwa natury i kultury UNESCO /w:/ Wybrane zagadnienia zarzadzania dobrami UNESCO w Polsce, red. Szmygin B., Warszawa 2015, s. 9-34.

5 Siwek A., Ewidencja i monitoring - filary systemu ochrony zabytków, Biuletyn Informacyjny PKN ICOMOS, styczeń - marzec 2016; Nr 1(32) 2016, s. 24-28.

6 Dobosz P., Paradygmat przysztych zmian w systemie prawnej ochrony zabytków i opiece nad nimi w Polsce /w:/ II Kongres Konserwatorów ..., s. 69-73.

7 Zalasińska K., Zeidler K., Wykład prawa ochrony zabytków, Warszawa - Gdańsk 2015, s. 173-183.

8 Soldani A., Jankowski D., Zabytki. Ochrona i opieka. Praktyczny komentarz do nowej ustawy, Zielona Góra 2004. 
bierze swój początek z wcześniejszych norm prawnych w tym zakresie, z drugiej wprowadza szereg nowości. Wśród nowości znalazły się konstrukcje dokumentów strategicznych opisanych w Rozdziale 8 pod tytułem „Krajowy program ochrony zabytków i opieki nad zabytkami oraz ochrona zabytków na wypadek konfliktu zbrojnego i sytuacji kryzysowych." "Wbrew tytułowi, w rozdziale tym odniesiono się nie tylko do dokumentów szczebla centralnego, ale i dokumentów przypisanych samorządom wojewódzkim, powiatowym i gminnym. ${ }^{10}$ Ustawodawca szczegółowo określił cele i zakres rzeczowy programów oraz organy odpowiedzialne za realizację wymienionych wyżej dokumentów i tryb ich funkcjonowania. Być może z tej przyczyny we wspomnianym, autorskim komentarzu do ustawy, nie poświęcono sprawie zbyt wiele uwagi, mimo nowatorskiego charakteru zapisów. ${ }^{11}$ Szerzej i wnikliwie nowy element systemu skomentował Rafał Golat, autor poczytnego komentarza do nowej ustawy. Zacytujmy fragmenty historycznego już omówienia:

„Rozdział niniejszy przewiduje niewystępujący na gruncie ustawy o ochronie dóbr kultury system programowania ochrony zabytków i opieki nad zabytkami, którego centralnym ogniwem jest krajowy program w tym zakresie /.../ Wprowadzenie wyraźnych rozwiązań w tym przedmiocie ma na celu wypracowywanie przez organy administracji odpowiedniej strategii postępowania, czyli opartej na doświadczeniu praktycznym polityki ochrony zabytków i opieki nad zabytkami na szczeblu ogólnokrajowym i lokalnym, tak aby uniknąć podejmowania nieprzemyślanych decyzji i wzmocnić system organizacyjny powyższej ochrony i opieki."12

Mamy zatem dowód, iż od początku postrzegano ów zapis, jako novum służące polityce ochronnej i racjonalnemu zarządzaniu dziedzictwem. Ustawodawca stworzył bowiem przejrzysty i komplementarny system dokumentów strategicznych odpowiadający strukturze administracyjnej państwa oraz zasadom zarządzania, w którym wskazał właściwe źródła informacji wyjściowych, wykonawców, mechanizm kontroli oraz reagowania na zmiany. Co najważniejsze system ów zakładał hierarchizację działań i celów, w odniesieniu do gmin, powiatów, województw i kraju. Można powiedzieć, że tak zaprogramowany system, to śmiałe otwarcie na nowoczesne tendencje w dyskusji o zarządzaniu dziedzictwem w skali międzynarodowej. ${ }^{13}$

Centralną składową tak skonstruowanego systemu jest krajowy program ochrony zabytków. Ustawa o ochronie zabytków i opiece nad zabytkami w Art. 84. stanowi, iż: „W celu stworzenia warunków niezbędnych do realizacji ochrony zabytków i opieki nad zabytkami minister włáciwy do spraw kultury i ochrony dziedzictwa narodowego inicjuje i opracowuje, przy pomocy Generalnego Konserwatora Zabytków, krajowy program ochrony zabytków i opieki nad zabytkami." Zatem określono cel działania oraz organy sprawcze i wykonawcze. W kolejnym artykule (art. 85 cyt. Ustawy) doprecyzowano zawartość programu, w którym: /.../ określa się, w szczególności, cele i kierunki działań oraz zadania

9 Ustawa z dnia 23 lipca 2003 roku o ochronie zabytków i opiece nad zabytkami, Dz. U. 2003, Nr. 162, poz. 1568. Tekst ujednolicony: Dz. U. 2014, poz. 1446; Dz. U. 2015, poz. 397, 774.

10 Ustawa o ochronie zabytków..., art. 87.

11 Soldani A., Jankowski D., Zabytki..., s. 109-111.

12 Golat R., Ustawa o ochronie zabytków i opiece nad zabytkami. Komentarz, Zakamycze 2004, s. 154.

${ }_{13}$ Piotrowska-Nosek K., Konwencja w sprawie ochrony światowego dziedzictwa kulturalnego i naturalnego, przyjęta w Paryżu dnia 16 listopada 1972 r. przez Konferencję Generalną Organizacji Narodów Zjednoczonych dla Wychowania, Nauki i Kultury na jej siedemnastej sesji /w:/ Konwencje UNESCO w dziedzinie kultury. Komentarz, red. Zalasińska K., Warszawa 2014, s. 262-264. 
w zakresie ochrony zabytków i opieki nad zabytkami, warunki i sposób finansowania planowanych działań, a także harmonogram ich realizacji." Określono też czteroletni cykl obowiązywania programu. Sformułowanie „W szczególności” oznacza, że lista celów nie jest zamknięta, a jej poszerzanie należy do inicjatyw Ministerstwa. ${ }^{14}$ Artykuł 86 odnosi się do trybu uchwalenia programu, a przypisanie tej funkcji Radzie Ministrów sytuuje ów akt w rzędzie istotnych dokumentów rządowych. Przywołany, w ustępie 2 cytowanego artykułu, obowiązek przedstawiania co 2 lata, przez Ministra Kultury iDziedzictwaNarodowego, RadzieMinistrów,sprawozdaniazrealizacjikrajowegoprogramu,wprowadza mechanizm monitoringu działań. ${ }^{15}$ Zatem istotą dokumentu jest jego cykliczność, weryfikowalność, a co za tym idzie elastyczne reagowanie na sygnały zewnętrzne w czteroletnich cyklach strategicznych. Ponadto w artykule 87, ustęp 6 wskazano, że: „Sprawozdanie z realizacji wojewódzkiego programu opieki nad zabytkami jest przekazywane Generalnemu Konserwatorowi Zabytków i właściwemu wojewódzkiemukonserwatorowizabytków w celujego wykorzystania przyopracowywaniu, aktualizacji i realizacji krajowego programu ochrony zabytków i opieki nad zabytkami." Zatem wskazano precyzyjnie źródło informacji dla aktualizacji krajowego programu ochrony zabytków, wiążąc go zarazem logicznie ze strategicznymi dokumentami wojewódzkimi. ${ }^{16}$

\section{KRAJOWY PROGRAM \\ DANE WYJŚCIOWE $\Rightarrow$ OPRACOWANIE $\Downarrow$ \\ REALIZACJA \\ $\Rightarrow \Leftarrow$ \\ AKTUALIZACJA \\ 合实 \\ $\Leftarrow$ SPRAWOZDANIE $\Leftarrow$ PODSUMOWANIE \\ $\Downarrow$ MONITORING}

1. Ustawowy model przepływu informacji przy realizacji i aktualizacji Krajowego Programu Ochrony Zabytków (oprac. AS).

Wspomniany, obszerny artykuł 87 w całości odnosi się do samorządowych dokumentów strategicznych w zakresie opieki nad zabytkami. W artykule tym zawarto jednocześnie istotę modelu komplementarnych dokumentów współtworzących zhierarchizowaną, regionalną i krajową politykę ochronną. Zatem na podstawie art. 87.1. ustawy o ochronie zabytków i opiece nad zabytkami „Zarząd województwa, powiatu lub wójt (burmistrz, prezydent miasta) sporządza na okres 4 lat odpowiednio wojewódzki, powiatowy lub gminny program opieki nad zabytkami." Owe programy przyjmuje odpowiednio sejmik województwa, rada powiatu i rada gminy, po uzyskaniu opinii wojewódzkiego konserwatora zabytków. Programy te są ogłaszane $\mathrm{w}$ wojewódzkim dzienniku urzędowym. Z realizacji programów zarząd województwa, powiatu i wójt (burmistrz, prezydent miasta) sporządza, co 2 lata, sprawozdanie,

14 Golat R., Ustawa..., s. 155.

15 O rodzajach monitoringu: Siwek A., Monitoring zabytków w kontekście zarządzania miejscem światowego dziedzictwa /w:/ Wybrane zagadnienia zarzadzania dobrami UNESCO ..., s. 147-166.

16 O potrzebie dostrzegania spójności polityki państwa i szczebla wojewódzkiego por. Wodnicka D., Dziedzictwo kulturowe w polityce rozwoju województwa /w:/ Dlaczego i jak w nowoczesny sposób chronić..., s. 153-156. 
które przedstawia się odpowiednio sejmikowi województwa, radzie powiatu lub radzie gminy. ${ }^{17}$ Wprawdzie nie wprowadzono tu obowiązku informowania o realizacji programu (sprawozdania) przez gminy i powiaty jednostek administracji samorządowej wyższego rzędu, jednak publiczny charakter dokumentów, w warunkach postępującej informatyzacji działań urzędowych, czyni te sprawozdania bardziej dostępnymi i publicznymi. Odnotujmy, że nie zobligowano również gmin i powiatów do przekazywania informacji o realizacji programu Wojewódzkim Konserwatorom Zabytków. Przepływ informacji między samorządem, a administracją rządową usankcjonowano jedynie na poziomie województwa, we wspomnianym ustępie 6 , art. 87. Osobnej uwagi wymaga ustęp 2 cytowanego art. 87. W sposób szczegółowy, ale zarazem na zasadzie zbioru otwartego („W szczególności”) ${ }^{18}$ określono w nim cele opracowywania samorządowych dokumentów strategicznych - programów opieki nad zabytkami. Cele te dotyczą włączenia problemów ochrony zabytków do systemu zadań wynikających z koncepcji przestrzennego zagospodarowania kraju, traktowania uwarunkowań ochrony zabytków, w tym krajobrazu kulturowego i dziedzictwa archeologicznego, przy uwzględnieniu uwarunkowań ochrony przyrody i równowagi ekologicznej, zahamowania procesów degradacji zabytków, eksponowania zabytków oraz walorów krajobrazu kulturowego, zwiększania atrakcyjność zabytków, dla potrzeb społecznych, turystycznych i edukacyjnych oraz generowania środków na ten cel, określenia warunków współpracy z właścicielami zabytków oraz tworzenia miejsc pracy związanych z opieką nad zabytkami.

Cele związane z troską o zachowanie substancji zabytkowej połączono z celami związanymi ze społeczną rolą zabytków oraz uwarunkowaniami ekonomicznymi.

Dopełnieniem modelu współdziałania dokumentów strategicznych i innych aktów prawa miejscowego lub dokumentów zarządczych są zapisy art. 18 cytowanej ustawy, w którym, w ustępach 1 i 2 czytamy, iż „przy sporządzaniu i aktualizacji koncepcji przestrzennego zagospodarowania kraju, strategii rozwoju województw, planów zagospodarowania przestrzennego województw, analiz i studiów z zakresu zagospodarowania przestrzennego powiatu, strategii rozwoju gmin, studiów uwarunkowań i kierunków zagospodarowania przestrzennego gmin oraz miejscowych planów zagospodarowania przestrzennego /.../ uwzględnia się krajowy program ochrony zabytków i opieki nad zabytkami”. Natomiast art. 19 ust. 1 i 2 wskazują, iż: „W przypadku gdy gmina posiada gminny program opieki nad zabytkami, ustalenia tego programu [uwzględnia się] /.../ w studium uwarunkowań i kierunków zagospodarowania przestrzennego gminy oraz w miejscowym planie zagospodarowania przestrzennego.” Przywołane artykuły określają rolę dokumentów strategicznych szczebla centralnego i gminnego w tworzeniu polityki przestrzennej i prawa miejscowego w zakresie gospodarowania przestrzenią zarówno w skali makro, jak i lokalnej. Tym samym ma być zapewniony związek i spójność polityki ochronnej z polityką przestrzenną. To interesujący element omawianego modelu, w znacznej mierze pozostający w sferze teorii, nieobecny w praktyce. Wreszcie logiczną klamrą dopinającą system jest art. 21 cytowanej ustawy, który wskazuje, iż: „Ewidencja zabytków jest podstawą dla sporządzania programów opieki nad zabytkami przez województwa, powiaty i gminy.” Mamy tu do czynienia z jednoznacznym wskazaniem źródła informacji, a co za tym idzie stopnia szczegółowości przewidywanego dla wspomnianych dokumentów. Jednocześnie mamy tu pośrednio potwierdzoną wolę, by za pośrednictwem prawa miejscowego, czyli planów zagospodarowania

\footnotetext{
17 Ustawa o ochronie zabytków..., art. 87, ust. 1-5.

18 Golat R., Ustawa..., s. 156-158.
} 
przestrzennego, ewidencja zabytków znajdowała odzwierciedlenie w zapisach ochronnych. ${ }^{19}$ Zauważmy jednocześnie, że w omawianym modelu zależności nie ma ustawowego zobowiązania uzależniania zapisów gminnego programu opieki nad zabytkami od analogicznych aktów innych jednostek samorządu (powiat, województwo), czy kraju, co można poczytać za niekonsekwencję systemu. ${ }^{20}$ Taka korelacja zapisów wydaje się najbardziej oczekiwana i uzasadniona, dla wspólnego budowania spójnej polityki ochrony zabytków w regionie, przy pełnym poszanowaniu specyfiki problematyki ochrony dziedzictwa w konkretnej gminie.

Podsumowując, można stwierdzić, iż ustawodawca w 2003 wprowadził w obieg prawny model funkcjonowania dokumentów strategiczno zarządczych, adresowanych do samorządu, rządowej administracji konserwatorskiej i rządowej administracji centralnej. Mimo niekonsekwencji i mankamentów zaproponowany model zarządzania strategicznego zjednej strony jawi się, jako element recepcji globalnej doktryny konserwatorskiej kreowanej w kręgach światowego dziedzictwa, z drugiej jakopróbawyjścia poza dotychczasoweramypolitykikonserwatorskiejwkraju.Program,jakodokument strategiczny, niezależnie od szczebla realizacji, ma na celu ukierunkować i zoptymalizować działania w zakresie ochrony dziedzictwa kulturowego, a w szczególności zabytków nieruchomych i krajobrazu, jako elementów o kluczowym znaczeniu dla tożsamości, historii i kultury danego obszaru. Jednocześnie hierarchizacja dokumentów i narzucająca się możliwość ich wzajemnego korelowania dają podstawy budowania spójnej polityki ochronnej od szczebla gminy, po centralny. Jednoznacznie określony $\mathrm{w}$ ustawie system sprawozdań z realizacji programów powinien stać się elementem regionalnego i krajowego monitoringu ochrony zabytków (lub szerzej dziedzictwa). Niestety, jak sygnalizowaliśmy we wstępie, ów obiecujący model współdziałania i zarządzania, w praktyce nie spełnia pokładanych nadziei. Dlaczego?

\section{Praktyka i bariery systemowe}

Z perspektywy ponad dekady obowiązywania „nowej” ustawy o ochronie zabytków i opiece nad zabytkami z 2003 można stwierdzić, że model oparty o współdziałające programy opieki nad zabytkami wdrażany jest w Polsce bardzo opornie. Nie zbudowano dotąd spójnego mechanizmu tworzenia komplementarnych polityk konserwatorskich w skali regionu i kraju. W wielu przypadkach programy w ogóle nie zaistniały, jako dokument publiczny. Z danych zbieranych w 2012 przez Narodowy Instytut Dziedzictwa wynika, że pod względem statystycznym zaledwie około $20 \%$ gmin w Polsce miało wówczas aktualny gminny program opieki nad zabytkami. ${ }^{21} \mathrm{Z}$ czego w dwóch województwach ten procent wynosił ponad 30\% (wielkopolskie 41,2\%, pomorskie 38,2\%) w 6 województwach mieścił się w przedziale $20-30 \%$, w 5 w przedziale $10-20 \%$ oraz w 3 poniżej 10\%. W 2012 swoistym rekordzistą było województwo lubelskie, gdzie odnotowano realizację gminnych programów opieki nad zabytkami

19 Tak rozumiemy korelację: ewidencja źródłem dla programów opieki (art. 21), programy opieki odzwierciedlane w dokumentach planistycznych (art. 19).

20 Potrzebę takich relacji wskazali Autorzy „Instrukcji” opracowanej w Krajowym Ośrodku Badań i Dokumentacji Zabytków (dziś NID), która jednak jest materiałem instruktażowym, a nie normą prawną w tym zakresie. Por. Błyskosz T., Fortuna-Marek A., Jagielska E., Liżewska I., Oszczanowska B., WelcJędrzejewska J., Gminny program opieki nad zabytkami. Poradnik metodyczny, Kurier Konserwatorski, Nr 3; 2009, s. 15-18.

21 Narodowy Instytut Dziedzictwa, wyniki ankiety przeprowadzanej przez Oddziały Terenowe w 2012 r., dane w dyspozycji Pionu Analiz i Strategii Zarządzania Dziedzictwem. 
dla 4,2\% gmin. W przypadku powiatów statystyki te wypadały jeszcze gorzej. W 3 województwach programy miało 25\% powiatów (opolskie, wielkopolskie, pomorskie), w 4 statystyka mieściła się w przedziale ponad 10\% poniżej 20\%, w 9 województwach było poniżej 10\%, z czego w dwóch uzyskano wynik 0\% (lubuskie i podlaskie). W przypadku programów wojewódzkich w 2012 nie było województwa, gdzie nie podjęto wysiłku sporządzenia takiego programu, ale nie wszędzie udało się zachować ich aktualność. W 3 województwach pracowano wówczas nad nowelizacją programu, który utracił aktualność. Obecnie z wyrywkowo pozyskiwanych danych wyłania się obraz pewnego postępu w ilościach realizowanych dokumentów strategicznych. Chociaż dane zamieszczone w „Wojewódzkim programie opieki nad zabytkami w Małopolsce na lata 2014-2017” nie nastrajają entuzjastycznie. ${ }^{22}$ W 2014 r. 30 gmin w Małopolsce posiadało aktualny program opieki, co stanowiło 16,48\% gmin w województwie. W skali powiatów były to 3 jednostki, czyli 13,64\% powiatów województwa. Według danych Urzędu Marszałkowskiego w okresie 2003-2013 w skali województwa małopolskiego obowiązywały 42 gminne programy opieki nad zabytkami, 5 powiatowych i 2 wojewódzkie, a kolejny wojewódzki na lata 2014-2017 był w opracowaniu. Trzeba przy tym odnotować, że tylko województwu udało się zachować ciągłość i odnawialność dokumentów. ${ }^{23}$ Trudno jednak dziwić się opieszałości samorządów, skoro wbrew zapisom ustawowym, mimo podejmowanych prób, pierwszy „Krajowy program ochrony zabytków” został przyjęty dopiero w 2014 r. na lata 2014-2017. ${ }^{24}$ Program ma charakter techniczny, porządkujący system i dotyczy działań które mogą być wykonane za pośrednictwem jednostek podległych Ministrowi Kultury i Dziedzictwa Narodowego, zatem nosi cechy bliższe programu opieki, niż wizji strategicznej dla polityki państwa w zakresie ochrony dziedzictwa.

Wśród ograniczeń, które spowalniały budowanie sytemu można wymienić kwestie ustawowo określonego źródła danych, czyli ewidencji zabytków. Ustawodawca z góry założył, że jej powstanie nie będzie łatwe, stąd początkowo ustalono 3 letni termin od daty wejścia w życie ustawy, na jej organizację. 25 Termin ten następnie prolongowano. Dyskusje wokół znaczenia i sprzeczności związanych z gminną ewidencją zabytków na pewno nie sprzyjają wykorzystywaniu jej, jako źródła dla programów strategicznych. ${ }^{26}$ Szczególnie podkreślenia wymaga wewnętrzny konflikt w konstrukcji ewidencji, która zzałożeniamiałapełnićfunkcjęinformacyjną, azczasemprzychylasiękucorazwyraźniejdopowiedzianej formie ochrony. ${ }^{27}$ Wątpliwości i niekonsekwencje w konstrukcji systemu można mnożyć. Już w warstwie

22 Wojewódzki program opieki nad zabytkami w Małopolsce na lata 2014-2017, red. Szpala A., Kraków 2014, s. 73-77.

23 Kolejno obowiązywały programy na lata 2005-2009; 2010-2013; 2014-2017. Program uchwalony dla Małopolski w 2005 był pierwszym w Polsce i dla części województw stał się dokumentem wzorcowym.

24 Ustawa o ochronie zabytków i opiece nad zabytkami z 23 lipca 2003, Art. 146: W terminie 12 miesięcy od dnia wejścia w życie ustawy, minister właściwy do spraw kultury i ochrony dziedzictwa narodowego opracuje krajowy program ochrony zabytków i opieki nad zabytkami.

25 Ustawa o ochronie zabytków i opiece nad zabytkami z 23 lipca 2003, Art. 143: W terminie 3 lat od dnia wejścia w życie ustawy, Generalny Konserwator Zabytków, wojewódzcy konserwatorzy zabytków i wójt (burmistrz, prezydent miasta) założą odpowiednio krajową, wojewódzką i gminną ewidencję zabytków.

26 Jafra T., Rola samorzadu terytorialnego w zakresie ochrony i opieki nad zabytkami /w:/ Prawne wyzwania ochrony dóbr kultury we współczesnym świecie, red. Dobosz P., Adamus M., Mazur A., Kraków 2015, s. 63-64.

27 Zalasińska K., Zeidler K., Wykład..., s. 69-72. 
tekstu ustawy zwraca uwagę niespójność terminologiczna. Ustawa wprowadza nienazywany wcześniej podział na opiekę i ochronę, odpowiednio przynależne do obowiązków administracji publicznej oraz dysponentów zabytków. ${ }^{28}$ Odnośnie programu krajowego użyto terminu „ochrony zabytków” (art. 85), a programy regionalne nazwano „programem opieki” (art. 87). Z nazwą tą sprzeczne są cele programów samorządowych określone $\mathrm{w}$ art. 87, przynależne do sfery ochrony, właściwej, zresztą zgodnie z logiką, dla działań administracji publicznej. Owa niekonsekwencja terminologiczna dał asumpt do opracowywania programów opieki ograniczonych tematycznie do obiektów stanowiących mienie komunalne. W takim ujęciu były to raczej plany działania, niż dokumenty strategiczne w rozumieniu systemów zarządzania. ${ }^{29}$ Prawdopodobnie takie rozumienie programów opieki nad zabytkami dało też podstawę do stwierdzenia, iż: „elementem fakultatywnym jest natomiast potrzeba uwzględniania w powyższych opracowaniach [studia uwarunkowań, mpzp] gminnych programów opieki nad zbytkami/.../. Gminne programy opieki nad zabytkami nie muszą być bowiem obowiązkowo opracowywane w każdej gminie /.../." ${ }^{30}$ Oczywiście można powiedzieć, że to błędna i incydentalna interpretacja, ale zarazem symptomatyczna. Trzeba zaznaczyć, że część samorządów przyjęła diametralnie odmienną interpretację opracowując programy opieki, jako dokumenty strategiczne o szerokiej podbudowie doktrynalnej i poznawczej. Przykładem takich opracowań są programy opieki województwa małopolskiego, doskonalone od prekursorskiej w skali kraju wersji z 2005, przez dwie kolejne edycje. ${ }^{31}$

Podsumowując można stwierdzić, że wdrażanie w praktyce ustawowo narzuconych systemowi ochrony zabytków dokumentów strategicznych pozostaje wciąż w sferze eksperymentów, a nie sprawnie działającego systemu. Oznacza to, iż w praktyce ochrony zabytków w Polsce niepodzielnie dominuje model kontroli administracyjno prawnej, nad systemem racjonalnego zarządzania, gdzie inicjatywy i działania poszczególnych interesariuszy podporządkowane są z góry założonej hierarchii celów.

\section{Wnioski}

System krajowych i regionalnych dokumentów strategicznych wprowadzony w ustawie z $2003 \mathrm{r}$. o ochronie zabytków i opiece nad zabytkami, jako model działania ma szereg zalet. Łączy się z nowym spojrzeniem na system ochrony zabytków w ogólności, tworzy model logiczny i zwarty (zwłaszcza w przypadku dokonania drobnych korekt współzależności). Jest drogą do szerszego angażowania samorządów do działań na rzecz ochrony zabytków oraz sposobem na lepsze pozyskiwanie danych o zasobie, potrzebach i realizacjach (monitoring systemu). Zarazem odwołuje się do narzędzi elastycznych, dających się weryfikować i optymalizować w określonych przedziałach czasu. Słabością systemu są niedostatki specjalistów w zakresie ochrony i zarządzania dziedzictwem, szczególnie na szczeblach powiatu i gminy, co przy nowatorstwie i wysokim poziomie wymagań, jakie niosą owe narzędzia odbija się na realizacji zadań. Słabością jest brak tradycji i doświadczeń w zarządzaniu dziedzictwem oraz niska ranga programów opieki w hierarchii samorządowych dokumentów

28 Ustawa o ochronie zabytków i opiece nad zabytkami z 23 lipca 2003, art. 4 i 5.

29 Fortuna-Marek A., Siwek A., Plany działania - jako element zarządzania miejscem światowego dziedzictwa [w:] Wybrane zagadnienia zarządzania dobrami UNESCO ..., s. 75-79.

30 Golat R., Ustawa... s. 43. Komentarz do art. 19.

31 Dokument z 2005 r. opracowano w Departamencie Edukacji i Kultury Urzędu Marszałkowskiego Województwa Małopolskiego pod kierunkiem J. Sepioła. 
strategicznych. Z punktu widzenia systemu słabością jest też niefunkcjonujący i niedookreślony formalnie przepływ informacji między szczeblami administracji przewidziany przez ustawodawcę. Tym niemniej ów model działania wiąże się z poważnymi szansami optymalizacji ochrony dziedzictwa, przez rozwój praktyki stosowania i doskonalenie narzędzi w kolejnych edycjach oraz wzrost znaczenia dziedzictwa zarówno w strategiach ochrony wartości, w rozwoju przemysłów czasu wolnego, jak i w kreowaniu wizerunku samorządów. Bez wątpienia przyjęcie krajowego programu ochrony zabytków przyczynia się do dopełnienia modelu i „uszczelnienia” systemu zarządzania dziedzictwem. Jednak w przyszłości potrzeba większej synergii dokumentów. Szansą jest szersze przejmowanie wzorów z rozwijającej się bujnie pragmatyki ochrony i zarządzania miejsc światowego dziedzictwa UNESCO. Jednak na finalny odbiór owego modelu wpływ mają też konkretne zagrożenia, wśród których do najistotniejszych należy ograniczona wydolność prawna i praktyczna systemu ochrony zabytków w kraju, pozostawanie programów li tylko w sferze teorii, skłonność do „pisanie na półkę”. Wciąż obecnym problemem jest złe określenie obszaru tematycznego programów - zbyt szerokie (ponad zakres możliwości oddziaływania), lub tendencyjnie zawężone pole tematyczne. Zagrożeniem zawsze obecnym jest potencjalna możliwość obniżania rangi problematyki dziedzictwa w polityce samorządowej wszystkich szczebli.

Wojewódzkie, powiatowe i gminne programy opieki nad zabytkami to narzędzia strategiczne, kreujące politykę, wyrażające wolę, określające kierunki działania (priorytety) dla optymalizacji ochrony konkretnych obiektów i obszarów zabytkowych, elementów dziedzictwa kulturowego regionu. Zapis ustawowy czyni je potencjalnym „systemem nerwowym” ochrony zabytków, zapewniającym przepływ informacji, koordynację i możliwość racjonalizacji działań, szczególnie przez hierarchizację celów. Jednak jakkolwiek ocenialibyśmy model wprowadzony w ustawie z 2003, to musimy przyznać, że dotąd nie został wdrożony zgodnie z intencją ustawodawcy. Owa konstatacja i analiza przyczyn mówią wiele już nie tylko o samym modelu, ale i o całym systemie ochrony dziedzictwa w Polsce. Po pierwsze wskazująnaliberalnystosunekdozapisówprawa-możliwośćdługotrwałegoignorowaniawprowadzonej normy prawnej i to na każdym szczeblu administracji. Dają wyobrażenie o wielkim zróżnicowaniu przygotowania (zarówno profesjonalnego, jak i mentalnego) samorządów do sprawowania ochrony dziedzictwa - od przykładów doskonałych, przekraczających ramy systemu, po zupełne systemu ignorowanie. Historia wdrażania i funkcjonowanie samorządowych programów opieki nad zabytkami, to też niewyzyskany w pełni przyczynek do dyskusji o docelowym kształcie systemu ochrony zabytków. Zarazem sygnał o zachowawczości praktyki ochrony zabytków. Sprawnie użytkowane są formy z dawna zakorzenione, jak rejestr zabytków, czy plany zagospodarowania przestrzennego. Nowości, takie ja park kulturowy, czy programy opieki przyjmują się z trudem i pomału. To konstatacja, której nie należy lekceważyć w budowie koncepcji zmian sytemu - powinny być ewolucyjne, odwołujące się do funkcjonujących rozwiązań i w ich ramach znajdować optymalizację. W tym kontekście lata 2003-2016 można potraktować jako okres „oswajania się” z nowym modelem ochrony i zarządzania dziedzictwem. Doświadczenia tego okresu należy spożytkować i dążyć do utrwalenia modelu, który zdaje się być obiecujący, ale wciąż niedostatecznie uregulowany (przepływy informacji) oraz wdrożony (mały procent realizacji). Nie należy jednak odrzucać koncepcji, bo można bez ryzyka stwierdzić, że w przyszłości zarządzanie, jako alternatywa ochrony, informacja jako zasób i dokumenty strategiczne, jako narzędzia będą tylko zyskiwać na znaczeniu. 
